\title{
DANO MORAL COLETIVO NO DIREITO DO TRABALHO
}

\author{
Rui Guimarães Sampaio \\ Advogado. Graduado no Curso de Direito da FA7. \\ O presente artigo origina-se de sua monografia de graduação, \\ que obteve $1^{\circ}$ lugar no Prêmio de Monografias Jurídicas Prof. \\ Agerson Tabosa, 2014-2, sob orientação do prof. Me. Paulo \\ Rogério Marques de Carvalho (FA7). \\ ruiguimaraes.sampaio@gmail.com
}

SUMÁRIO: Introdução. 1. Dano moral coletivo. 2. Crítica ao termo. 3. Hipóteses de configuração do dano moral coletivo trabalhista. 3.1 Da redução à condição análoga à de escravo. 3.2 Da revista íntima. 3.3 Do descumprimento das leis trabalhistas. 3.4 Descumprimento das normas de medicina e segurança do trabalho. 3.5 Da terceirização ilícita. Considerações finais. Referências.

Resumo: O presente trabalho tem como escopo analisar de forma crítica o dano moral coletivo, bem como seu conceito e incidência no campo do direito trabalhista. Em momento posterior se examina o dano moral coletivo sob a ótica laboral, analisando precipuamente suas hipóteses de configuração através de julgados dos tribunais trabalhistas pátrios. Ressalte-se que há crítica formulada quanto ao termo dano moral coletivo, tendo em vista que melhor seria utilizar o termo dano extrapatrimonial coletivo, pois neste não se remete à ideia de dor, vexame ou abalo psicológico, efeitos que de fato não podem ser observados no âmbito coletivo. Assim, o dano moral coletivo, diante da evolução doutrinária e jurisprudencial, constitui uma ofensa aos direitos pertencentes à coletividade, de modo que há a sua ocorrência quando se perpetra algum direito transindividual ofendendo principalmente a dignidade da pessoa humana. No plano laboral, o dano moral coletivo mostra-se bastante incidente, principalmente nos casos de redução à condição análoga de escravo, revista íntima, descumprimento das leis trabalhistas, descumprimento das normas de medicina e segurança do trabalho. O objeto aqui estudado, tendo em vista a sua crescente evolução e as várias interpretações sobre as nuances deste, apresenta-se, por vezes, divergente, principalmente no campo da doutrina, haja vista a posição de alguns autores em não acatar a existência do dano moral coletivo. Para a feitura do trabalho foram utilizadas obras do ramo do Direito, precipuamente aquelas pertencentes ao campo da responsabilidade civil, do Direito Trabalhista, da Tutela Coletiva, além de obras específicas sobre dano moral, dano moral trabalhista e dano moral (extrapatrimonial) coletivo, usando-se um método dedutivo, isto é, partindo de premissas gerais com o fulcro de chegar a uma premissa específica.

Palavras-chave: Direito do Trabalho. Dano Moral Coletivo. Dano Extrapatrimonial Coletivo. Interesses Transindividuais. 


\section{INTRODUÇÃo}

O dano moral constitui campo de estudo da Responsabilidade Civil, portanto se deve entender que ele necessita dos elementos básicos da responsabilidade civil, quais sejam: a conduta do agente, o dano e o nexo causal, de modo a caracterizar o dever de indenizar. Ressalte-se que a culpa se mostra apenas como elemento acidental, sendo necessária apenas para caracterizar a responsabilidade subjetiva, na qual o elemento culpa é necessário, ao passo que na responsabilidade objetiva a culpa é dispensável.

Quanto ao dano moral, tem-se que este sempre esteve ligado à ideia de dor, vexame, abalo psicológico, sendo sua reparação considerada, inclusive, como uma forma de atenuar a dor sofrida. Entretanto, essa visão resta superada, tendo em vista que os elementos psicológicos são apenas consequências do dano gerado. $\mathrm{O}$ dano moral é, na verdade, um ataque à dignidade da pessoa humana e aos direitos de personalidade, gerando efeitos não na esfera patrimonial diretamente, mas sim, na extrapatrimonial.

Diante desses conceitos, atuando em conjunto para formar a ideia de dano moral coletivo, aparecem os direitos metaindividuais ou transindividuais como sendo aqueles que ultrapassam a mera esfera da individualidade, passando a atingir a coletividade, sendo essa determinável ou indeterminável.

Para a feitura do trabalho foram utilizadas obras do ramo do Direito, precipuamente aquelas pertencentes ao campo da responsabilidade civil, do Direito Trabalhista, da Tutela Coletiva, além de obras específicas sobre dano moral, dano moral trabalhista e dano moral (extrapatrimonial) coletivo, usando-se um método dedutivo, isto é, partindo de premissas gerais com o fulcro de chegar a uma premissa específica.

Foram utilizados durante o presente trabalho julgados dos Tribunais Trabalhistas, notadamente as ações civis públicas que tramitam ou tramitaram na Justiça do Trabalho com o fito de explicitar o que vem se entendendo hodiernamente por dano moral coletivo nas relações de trabalho, assim como se demonstram as várias facetas do objeto em estudo, como a questão da reparabilidade, responsabilidade, condenação, destinação do quantum, solidariedade e prescrição.

Tem-se como objetivo geral demonstrar a aplicação e as particularidades do dano moral coletivo no campo do Direito do Trabalho, usando para isso livros específicos da área trabalhista e de direito coletivo, bem como se utiliza os julgados dos tribunais para demonstrar como o Judiciário tem enfrentado o tema.

Saliente-se, que melhor seria utilizar a expressão dano extrapatrimonial coletivo, tendo em vista que o dano moral sempre esteve ligado à ideia de dor, sofrimento, o que de fato não pode se auferir em uma coletividade. Reputa-se com melhor rigor técnico a expressão dano extrapatrimonial coletivo, pois remete à ideia de um dano que não estaria atingindo determinada esfera patrimonial, mas sim, a esfera extrapatrimonial, mesmo que em decorrência do dano extrapatrimonial haja repercussão na esfera patrimonial.

\section{Do Dano Moral Coletivo}

A teoria da responsabilidade civil, diante da evolução da Constituição e da sociedade, vem se modificando no sentindo de propiciar a efetiva tutela dos direitos garantidos à coletividade. A partir dessa evolução passou o sistema jurídico a tutelar não somente o dano patrimonial, mas também o extrapatrimonial, como é o exemplo do dano moral; este, como posteriormente se demonstra, é passível de reparação quando há agressão também aos direitos da coletividade. 
Passadas tais considerações preliminares, tenta-se estabelecer aqui um conceito que, de alguma forma, procure expressar a ideia de dano moral coletivo. Bittar Filho, ao explicitar dano moral coletivo, define-o como sendo:

[...] injusta lesão da esfera moral de uma dada comunidade, ou seja, é a violação antijurídica de um determinado círculo de valores coletivos. Quando se fala em dano moral coletivo, está-se fazendo menção ao fato de que o patrimônio valorativo de certa comunidade (maior ou menor) idealmente considerada, foi agredido de uma maneira absolutamente injustificável do ponto de vista jurídico (1994, p. 54).

Explicita, nesse âmbito, Compiani (apud COSTA) que: “[...] denomina-se dano moral coletivo aquele experimentado por um conjunto de pessoas cuja raiz da lesão seja um interesse grupal ou social" (2009, p. 68).

Para Souto Maior:

[...] nos termos dos art. 186 e 187 do Código Civil, aquele que, ultrapassando os limites impostos pelo fim econômico ou social, gera dano ou mesmo expõe o direito de outrem a um risco, comete ato ilícito. O ilícito, portanto, se perfaz pela provocação de um dano dos interesses sociais e econômicos, coletivamente considerados (2011, p. 1319).

Costa corrobora para o tema explicando que:

Considerando que o princípio da dignidade da pessoa humana convolou-se no centro axiológico do ordenamento jurídico, além de possuir dimensão unitária e social, instituindo verdadeira cláusula de tutela e dever geral de respeito à personalidade humana, tem-se como consequência o fato de que toda violação da projeção coletiva desse princípio constitucional, consubstanciado em interesses/direitos extrapatrimoniais essencialmente coletivos (difusos e coletivos em sentido estrito) e, portanto, não adstritos a pessoas singulares, configurará dano moral coletivo (2009, p. 70).

Com efeito, não é necessário para que fique caracterizado o dano moral à coletividade um abalo psicofísico, mas sim, uma ofensa direta àqueles direitos transindividuais. Assim, dano moral coletivo, para efeito de conceituação, transparece a observação de ofensa direta aos direitos da coletividade, isto é, os transindividuais, os quais possuem natureza extrapatrimonial, independentemente de aferimento de abalo psicológico, violando precipuamente o princípio da dignidade e os direitos de personalidade.

Portanto, demonstra-se aqui o dano moral coletivo como sendo a injusta lesão aos interesses de natureza transindividual que fere precipuamente a dignidade da pessoa humana, não afetando a esfera patrimonial, mas sim, a extrapatrimonial, utilizando-se, para tanto, dos conceitos de dano moral, interesses transindividuais e a configuração de tais institutos. Serão oportunamente demonstradas as hipóteses de configuração do dano moral coletivo e principalmente a sua configuração no Direito do Trabalho, tendo em vista que o campo das relações trabalhistas é extremamente fértil para o surgimento de danos, notadamente pelo dano moral coletivo.

\section{Da Crítica Ao Termo Dano Moral Coletivo}

Deve-se atentar para o fato de que a expressão dano moral coletivo não está em perfeita harmonia com a teoria do dano, uma vez que nem toda lesão à personalidade e à dignidade humana resulta em dor, vexame, asseverando Medeiros Neto que “[...] o termo moral, pela sua equivocidade, sempre esteve mais próximo de uma tradução de dano relacionado com o sentimento e a dor física ou psíquica, a revelar [...] uma posição teórica e incompleta” (2007, p. 123). 
De fato, o dano moral sempre esteve atrelado à ideia de dor, abalo psicológico, o que por óbvio não há como se auferir tal critério no âmbito da coletividade. É que é inconcebível a ideia de que a coletividade possa sofrer abalo psicológico.

Nesse sentindo, orienta Medeiros Neto que mais coerente seria usar, por estar o dano moral mormente ligado à ideia de dor psicológica, sofrimento, a expressão dano extrapatrimonial coletivo, pois nesta há a ideia de um dano que não pode ser quantificado em pecúnia, não se limitando aos abalos psíquicos sofridos (2007, p. 124). Assim, a expressão extrapatrimonial traduziria melhor o dano gerado às coletividades, pois, em inúmeros casos, como se verá, há possibilidade de ocorrência de dano a uma esfera que não seja patrimonial, isto é, uma esfera extrapatrimonial, não havendo qualquer ligação com a dor, vexame ou abalo psicológico.

A crítica resta evidenciada quando se citam os exemplos de bens jurídicos que necessitam da tutela coletiva, mas que, quando lesados, não transparecem a ideia de dor ou sofrimento psicológico. Assim, por exemplo, quando a $\mathrm{CF} / 88$ estabelece que todos terão direito a um meio ambiente saudável, eventual dano a tal direito não é suscetível, em regra, de gerar dor ou sofrimento à coletividade de pessoas, em que pese residir em tal caso um dano extrapatrimonial.

Costa aduz nessa seara que:

[...] a expressão dano moral, justamente pelo dato de evocar aspectos de índole subjetiva como salientado, não conseguiria açambarcar hipóteses de danos havidos em interesses extrapatrimoniais e igualmente postados ao largo da esfera do sentir tais como direitos inerentes à projeção de valores e bens ínsitos à dignidade humana, vieses individual e coletivo $(2009$, p. 65).

Corroborando a crítica aqui evidenciada, têm-se alguns julgados utilizando a expressão dano extrapatrimonial coletivo, afastando desta qualquer ideia de dor ou sofrimento, como é o caso do Recurso Ordinário n ${ }^{\circ}$ 0009900-65.2008.5.03.0083, oriundo do Tribunal Regional do Trabalho da

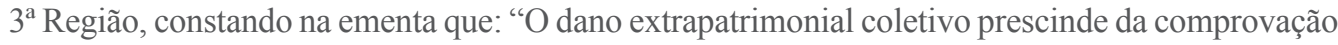
de dor, de sofrimento e de abalo psicológico, suscetíveis de apreciação na esfera do indivíduo, mas inaplicável aos interesses difusos e coletivos" (BRASIL, 2014, on-line).

Assim, por rigor conceitual, melhor seria usar a expressão dano extrapatrimonial coletivo, tendo em vista que a expressão moral ainda vincula a ideia de abalo psíquico, remetendo à índole subjetiva da vítima, e nem sempre um dano à coletividade gerará abalos psicológicos nas vítimas, mesmo porque dificilmente haveria possibilidade de apuração.

Contudo, utilizam-se ao longo do presente trabalho ambas as expressões como sinônimas, uma vez que elas são consagradas pela doutrina e jurisprudência.

\section{Hipóteses de Configuração do Dano Moral Coletivo Trabalhista}

A esfera trabalhista é ambiente fértil para que ofensas aos direitos das coletividades ocorram, de modo que:

\footnotetext{
No âmbito trabalhista, podemos afirmar que configura o dano moral coletivo o descumprimento, por parte dos empregadores, tais como: direito ao piso salarial ou normativo da categoria; direito à realização periódica de exames médicos; direito à saúde, higiene e segurança do trabalho; direito à jornada de trabalho estabelecida em lei (8 horas diárias ou 44 semanais); manter em seus quadros funcionais empregados sem registro; assim como discriminações que envolvam gênero, idade, saúde e ideologia na admissão ao emprego ou na vigência do contrato de trabalho (MELO, 2007, p. 85).
} 
Desse modo, passa-se a esposar alguns casos julgados pelos tribunais trabalhistas sobre a configuração do dano moral coletivo, de forma que se observa a plena aplicabilidade do dano moral coletivo na Justiça do Trabalho, sendo este um dano que fira diretamente os interesses da coletividade e a dignidade humana, seja ela pela desobediência da legislação laboral imposta, seja por situações que per si degradem a personalidade do indivíduo.

\subsection{Da redução à condição análoga de escravo}

Nas relações de trabalho, o dano moral torna-se cada vez mais evidente, quando, a título de exemplo, há redução dos trabalhadores à condição análoga de escravo. Nesse caso, não há somente o crime previsto no art. 149 do Código Penal, mas também dano à coletividade, gerando o dever de indenizar.

Na oportunidade do Recurso Ordinário ${ }^{\circ}$ 0000742-41.2012.5.03.0084, julgado pelo Tribunal Regional do Trabalho da $3^{\text {a }}$ Região, constataram-se as condições degradantes em que estavam sendo submetidos determinados trabalhadores rurais, ferindo-lhes diretamente a dignidade. Observe-se um trecho do depoimento, que consta no inteiro teor do acórdão, de um dos trabalhadores:

[...] que quando chegou na fazenda, encontrou o vaqueiro Tiago, que mostrou onde era para roçar [...] que o vaqueiro já foi falando que não tinha alojamento que continuaram a roçar e nada de dinheiro; que o Tião não apareceu para medir o serviço; que o Tiago falou que o Tião iria levar um remédio para os bezerros e aproveitaria para medir o serviço, mas não apareceu; que ficou sabendo que receberia $\mathrm{R} \$ 35,00$ por hectare roçado; que começou no dia 14/03/2011; que ficou sabendo o nome do dono da fazenda por estes dias; que por enquanto não recebeu nada; que ainda bem que trouxe um dinheirinho do norte de Minas, porque senão ia passar precisão, ficar com fome; que agora zerou, não tem dinheiro para voltar para casa; que gastou o que tinha com comida; que quando chegou pegou um arroz, macarrão, feijão, com uns meninos que trabalha na carvoaria, lá perto; que pagou graças a Deus [destacou-se], que tá devendo obrigação para eles, porque eles é que salvou nós para iniciar o serviço; que não tinha nada para comer [...] que trabalhava de segunda a domingo, que só descansou na sexta-feira santa [...] que usava garrafa do seu irmão que trouxe de Itacarambi para beber água, quando trabalhava; que a água era de córrego de lá, uma mina d'água; que a água era clara, mas salobra, que o problema era que o gado bebia água de lá também; que o gado ficava dentro desta água, que a água é rasinha, que o gado ta bebendo e entra dentro [destacou-se]; [...] quando chovia tinha que ficar sentado, porque molhava todo o colchão, aí embolava o colchão e sentava em cima; que tinha que esperar a chuva passar e continuar dormindo, que o banho era no tanque bebedor de gado, que dava uma coceira brava no corpo [...]. (BRASIL, 2013, on-line)

Essas condições impostas demonstram claramente a ofensa à dignidade da pessoa humana, de modo que não se atinge somente o trabalhador em si considerado, mas também valores pertencentes a toda coletividade e consignados na Constituição Federal de 1988, movidos pela solidariedade preconizada por ela, gerando um sentimento de repulsa social pela conduta perpetrada, havendo, por certo, o dano moral coletivo. Foi por essa razão que o Tribunal acima aludido deixou consignado em sua fundamentação que:

Escravizar é violar direitos fundamentais e difusos da sociedade, consagrados na Constituição Federal de 1988, entre os quais se destacam: a proteção à dignidade humana (art. $1^{\circ}$, III); os valores sociais do trabalho e da livre iniciativa (art. $1^{\circ}$, IV), a inviolabilidade do direito à vida, à liberdade, à igualdade, à segurança (art. $\left.5^{\circ}, c a p u t\right)$, a construção de uma sociedade livre, justa e solidária (art. $3^{\circ}$, I); o princípio da legalidade 
(art. $\left.5^{\circ}, \mathrm{II}\right)$; não submissão à tortura ou a tratamento desumano ou degradante ( $\operatorname{art.} 5^{\circ}$, III); a inviolabilidade da intimidade, da vida privada, da honra e da imagem (art. $5^{\circ}$, $\mathrm{X}$ ); a liberdade de exercício de trabalho, ofício ou profissão (art. $5^{\circ}$, XIII); a liberdade de locomoção (art. $5^{\circ}$, XXIII); a proibição de imposição de pena de trabalhos forçados e cruéis (art. $5^{\circ}$, XLVI); a proibição de prisão civil por dívida (art. $5^{\circ}$, LXVII). [...] A proibição de escravidão é um direito de toda a sociedade e, consequentemente, da humanidade, como expressam as declarações internacionais. [...] A conduta do réu causa repulsa e viola direitos difusos de toda a coletividade, na medida em que o empregador se olvidou de que estava lidando com pessoas e submeteu-as a condição degradante e, por isso, merece repressão severa, a fim de imprimir na sua consciência valores éticos e morais básicos, como o de que se deve tratar de forma digna as pessoas que lhe prestam serviços [destacou-se].

A posição dos tribunais trabalhistas não tem sido outra quanto à condenação de danos morais coletivos, quando constatadas as condições degradantes de trabalho. Observe-se a ementa do acórdão proferido no Recurso Ordinário nº 00245-2004-811-10-00-3 oriundo do Tribunal Regional da $10^{\text {a }}$ Região:

TRABALHO EM CONDIÇÕES ANÁLOGAS À DE ESCRAVO. DANO MORAL COLETIVO. Dadas as condições degradantes em que se encontravam os trabalhadores, restaram violados os direitos humanos, violação essa que o Brasil comprometeu-se a reprimir em decorrência de Tratados Internacionais. Recurso provido. (BRASIL, 2005, on-line)

Nesse sentido, também há julgado do Tribunal Superior do Trabalho. É o que se depreende através do teor da decisão dos embargos de declaração no Recurso de Revista $n^{\circ}$ 178000-13.2003.5.08.0117 (BRASIL, 2012, on-line), em que decidiu esse Tribunal manter a condenação da Justiça Trabalhista do Pará que determinou para a reclamada o pagamento de R\$ 5 milhões de indenização, a título de dano moral coletivo, por reduzir trabalhadores à condição análoga a de escravo, tendo em vista que praticava atos como o não fornecimento de água potável a seus funcionários, ausência de instalações sanitárias, trabalhadores doentes e sem assistência médica, não pagamento dos salários até o quinto dia útil do mês, não concessão do repouso semanal remunerado.

\subsection{Da revista íntima}

As revistas íntimas como práticas abusivas do poder diretivo do empregador estão aptas a gerar o dano moral coletivo, seja porque há previsão expressa da CLT proibindo a prática, seja porque fere diretamente a intimidade do ser humano, protegido pela Carta Magna, afetando não somente o trabalhador, mas determinado grupo de trabalhadores, sendo uma verdadeira ofensa aos direitos coletivos em sentido estrito.

Nesse diapasão, decidiu o Tribunal Regional do Trabalho da $20^{a}$ Região, no Recurso Ordinário $n^{\circ}$ 00202-2003-003-20-85-5, que configura dano moral coletivo a prática de submissão dos empregados à revista íntima, tratando os empregados como se criminosos fossem, uma vez que a revista procedida era similar à revista policial. Observe-se a ementa:

DANO MORAL COLETIVO - CONFIGURAÇÃO - REVISTA ÍNTIMA DE EMPREGADOS. Tendo sido demonstrado que a revista efetivada pela empresa em seus empregados, a despeito de não ser realizada com excessos vexatórios, os submetia à humilhação de um procedimento em muito similar às 'revistas' procedidas pela autoridade policial, deixando antever a dúvida do empregador quanto à integridade moral dos empregados, tratando-os como sujeitos da prática de infração penal, constata-se 


\begin{abstract}
a extrapolação dos limites de seu poder diretivo ao adotar a prática de revista íntima em suas dependências, máxime quando poderia ter utilizado outros meios para controle e vigilância de seus produtos. Ilícito e desnecessário o constrangimento físico e moral imposto com apalpadelas pelo corpo e com a suspeita velada, ofendendo a sua honra e a sua intimidade, sendo possível a tutela coletiva dos trabalhadores em pleito indenizatório. Dano moral configurado. (BRASIL, 2004, on-line)
\end{abstract}

Nota-se, nesse caso, que a violação excede os meros interesses individuais, atacando um grupo de trabalhadores ligados por uma relação jurídica base, gerando uma ofensa aos direitos coletivos em sentido estrito.

Ressalte-se que esta prática, que encontra proibição legal no art. 373-A da CLT, considerando o citado Tribunal que a desconfiança nos empregados não pode sobrepor a dignidade humana, sob pena de se estar violando a honra e intimidade dos empregados, afeta diretamente o grupo de trabalhadores.

\title{
3.3 Do descumprimento das leis trabalhistas
}

Configura-se também dano moral coletivo pela desobediência da legislação laboral no que tange às normas trabalhistas de observação obrigatória, isto porque tais normas garantem ao empregado a dignidade na realização de seu trabalho, valor este sempre em conflito com o interesse do empregador.

É o que se infere do Recurso Ordinário no 01606-2011-008-10-00-0 em que o empregador descumpria as regras dos intervalos intrajornada e interjornada, prejudicando diretamente seus empregados, situação esta que evidencia claramente ofensa à dignidade humana. Veja-se como restou ementado o referido Recurso:

\begin{abstract}
AÇÃO CIVIL PÚBLICA. MINISTÉRIO PÚBLICO DO TRABALHO. LEGITIMIDADE ATIVA. DIREITOS COLETIVOS. Nos termos dos arts. 127, 129 da CF; 83, III, da Lei Complementar 75/1993, está legitimado o Ministério Público do Trabalho para ajuizar ação civil pública para a defesa de interesses coletivos, quando desrespeitados os direitos sociais constitucionalmente garantidos, aí incluídos os individuais homogêneos, conforme a definição dada pelos incisos I, II e III do art. 81 do CDC. DANO MORAL COLETIVO. DESCUMPRIMENTO DE OBRIGAÇÕES TRABALHISTAS. INDENIZAÇÃO. 1. O descumprimento, pelo empregador, das obrigações referentes aos limites legais do trabalho, bem como do intervalo intra e interjornada, revela conduta prejudicial aos empregados, especialmente no tocante à sua saúde e segurança, além de ferir a ordem jurídica [destacou-se]. 2. Aflorando da prática lesão a direitos transindividuais, emerge o dever de reparação genérica à sociedade pelos danos causados. (BRASIL, 2013, on-line)
\end{abstract}

Destaque-se que o simples descumprimento da legislação trabalhista não ensejará a indenização por danos morais coletivos. É que, para que fique caracterizado o dano moral (extrapatrimonial) coletivo, a ofensa deve transcender os limites individuais, devendo haver certo grau de reprovabilidade diante da ordem jurídica. Foi dessa maneira que entendeu o Tribunal Regional do Trabalho da $3^{\text {a }}$ Região, na ocasião do julgamento do Recurso Ordinário $n^{\circ} 0000556$ 45.2013.5.03.0096, em que restou consignada a seguinte ementa:

DANO MORAL COLETIVO. CARACTERIZAÇÃO. A caracterização do dano moral coletivo está ligada à ofensa, em si, a direitos difusos e coletivos, cuja essência é tipicamente extrapatrimonial, não havendo, portanto, necessidade de comprovação de um prejuízo material, bem como de uma perturbação psíquica da coletividade. Com efeito, o que deve ser analisado é a gravidade da violação cometida frente à ordem 
jurídica, sendo prescindível a demonstração da repercussão de eventual violação na consciência coletiva do grupo social, uma vez que a lesão moral sofrida por este decorre, exatamente, da injusta lesão a direitos metaindividuais socialmente relevantes [destacou-se]. Portanto, não é qualquer desobediência à legislação trabalhista que caracteriza o dano moral coletivo. Nesse passo, no plano coletivo, assim como no âmbito individual o exame do dano moral deve ser realizado com cautela, inclusive para evitar a sua banalização. Por exemplo, quando o descumprimento da legislação trabalhista está relacionado a normas de segurança no trabalho, expondo os trabalhadores daquela coletividade a riscos iminentes, ou outro exemplo, no caso de trabalho escravo e infantil, tais violações consistem em lesões a direitos fundamentais constitucionais - como a dignidade da pessoa humana, os valores sociais do trabalho - fundamentos do Estado Democrático de Direito - atingindo toda a sociedade, o que autoriza a imposição de indenização. (BRASIL, 2014, on-line)

Dessa forma, é patente que o descumprimento da legislação trabalhista em detrimento do empregado poderá gerar danos morais coletivos, afetando diretamente uma categoria de trabalhadores.

\subsection{Descumprimento das normas de medicina e segurança do trabalho}

Ainda nesta seara, pode-se observar a caracterização do dano moral coletivo quando se trata do meio ambiente de trabalho, mormente quando ele se apresenta inseguro para que se exerça labor decorrente da desobediência às regras de medicina e segurança do trabalho. É o caso do Recurso Ordinário n ${ }^{\circ} 6853520115010077$, oriundo do Tribunal Regional da $1^{\text {a }}$ Região, o qual, por oportuno, colaciona-se a ementa:

RECURSO ORDINÁRIO. VIOLAÇÃO ÀS NORMAS DE MEDICINA E SEGURANÇA DO TRABALHO. DANO MORAL COLETIVO. A redução dos riscos inerentes à atividade laborativa, por meio das normas de saúde, higiene e segurança, constitui-se em direito social dos trabalhadores urbanos e rurais, nos exatos termos do inciso XXII, do artigo $7^{\circ}$, da Constituição Federal e obrigação do empregador, nos termos do artigo 154 e seguintes da CLT. A garantia constitucional do meio ambiente de trabalho saudável permite que se estenda uma proteção erga omnes, atrelando-se a efetividade de tal direito às tutelas preventivas que atendem a interesse de uma coletividade. $\mathrm{O}$ desrespeito a direito dessa natureza evidencia um dano moral coletivo, que se dissocia da ideia de dor psíquica, própria da pessoa física, direcionando-se para valores compartilhados socialmente que traduzam natureza coletiva. (BRASIL, 2014, on-line)

Portanto, os Tribunais têm atribuído grande valor ao meio ambiente de trabalho seguro, uma vez que este se caracteriza como uma conquista do trabalhador, estatuído no art. $7^{\circ}$, inc. XXII, da Constituição Federal de 1988, o qual preconiza que "são direitos dos trabalhadores redução dos riscos inerentes ao trabalho, por meio de normas de saúde, higiene e segurança".

Assim, decidiu o Tribunal Superior do Trabalho ao julgar o Recurso de Revista $n^{\circ}$ 15500-56.2010.5.17.0132, no qual se manteve a condenação por danos morais coletivos imposta pelo Tribunal Regional do Trabalho da $17^{\mathrm{a}}$ Região. Na resenha fática do processo em comento, que consta no inteiro teor do acórdão, descreveu-se a fiscalização do Ministério do Trabalho e Emprego no setor de extração de rochas ornamentais no Estado do Espírito Santo, em que se constatou em determinada empresa a seguinte situação:

Não havia qualquer tipo de sistema de proteção coletiva contra quedas, constituído por guarda-corpo e rodapé, gerando assim risco de acidentes. 
[...] deixou de dotar as mangueiras e conexões de alimentação de perfuratriz sob esteira, que estava em operação, de dispositivo auxiliar que garanta a contenção da mangueira, evitando seu ricocheteamento em caso de desprendimento acidental, gerando dessa forma risco aos trabalhadores [...]

[...] vem utilizando reiteradamente plano de fogo não elaborado por profissional legalmente habilitado (engenheiro de mina ou engenheiro civil) e segundo informações dos representantes da empresa, os planos de fogo são elaborados pelo técnico em mineração [...]. (BRASIL, 2013, on-line)

Pelo manifesto desrespeito às normas de medicina e segurança do trabalho, assim como o próprio desrespeito à vida dos trabalhadores, entendeu o TST que tal dano ultrapassa a mera esfera da individualidade, afetando diretamente os valores preconizados pela coletividade, de modo que restou o acórdão assim ementado:

\begin{abstract}
RECURSO DE REVISTA. DANO MORAL COLETIVO. DESCUMPRIMENTO DE OBRIGAÇÕES TRABALHISTAS. NORMAS DE SEGURANÇA DO TRABALHO. Consoante registrou o Tribunal a quo, está comprovado que a ora recorrente incorreu em conduta prejudicial aos seus empregados, ao descumprir as normas referentes à segurança e à medicina do trabalho. Ora, aquele que por ato ilícito causar dano, ainda que exclusivamente moral, fica obrigado a repará-lo. Assim, demonstrado que a recorrente cometeu ato ilícito, causando prejuízos a um certo grupo de trabalhadores e à própria ordem jurídica, não merece reparos a decisão proferida pela instância ordinária que a condenou a indenizar os danos morais coletivos [destacou-se]. Recurso de revista conhecido e não provido. (BRASIL, 2013, on-line)
\end{abstract}

Nessa mesma esteira, é de se notar o Recurso Ordinário ${ }^{\circ} 0000028$ 82.2010.5.06.0144, do Tribunal Regional do Trabalho da $6^{\text {a }}$ Região, o qual manteve a condenação de indenização por danos morais coletivos imposta pelo juízo singular. No aludido processo, entendeu-se que o desrespeito às normas de medicina e segurança do trabalho afeta não só o trabalhador, mas também a coletividade, uma vez que essas normas têm o teor de prevenir os tão indesejáveis acidentes do trabalho, sendo um valor preconizado pela sociedade, de modo que a sua infringência lesa os interesses da coletividade. Nesse sentido, veja-se a fundamentação reiterada pelo Regional:

Na perspectiva da coletividade, de se intuir que o tratamento constitucional dispensado ao meio ambiente na condição de direito-dever, oponível erga omnes, tem flagrante intenção de estender uma proteção também erga omnes e que a efetividade de tal direito está atrelada às tutelas preventivas. Se a tutela preventiva atende a interesse de uma coletividade, em caso de efetivação do dano ambiental, por óbvio que o desrespeito a direito dessa natureza atinge a coletividade, que é lesada e, por conseguinte [destacou-se], faz jus à reparação / compensação do dano e, sendo possível, ao restauro do direito violado, reequilibrando-se o meio ambiente atingido [...]

Diante dos fatos comprovados, mediante farta documentação que sequer foi impugnada pelo demandado, considerada a valoração de prova supra e a subsunção normativa aos fatos, tenho por evidenciado o dano moral coletivo, a atuação ilícita do réu e o nexo causal, destacada a conduta culposa do demandado, que vem descumprindo há anos as normas de medicina e segurança do trabalho, agindo de modo ilícito, sem adimplir sua obrigação de zelar pela integridade física de todas as pessoas que circulavam naquele meio ambiente [destacou-se], inclusive impondo risco além do que o ordenamento jurídico tem por ordinário naquela atividade, sendo alvo destacado desse risco todos os trabalhadores do demandado. [...]. (BRASIL, 2011, on-line) 
Observa-se, portanto, a clara incidência do dano moral coletivo nas relações trabalhistas quando há desrespeito às normas de medicina e segurança do trabalho, afetando diretamente o meio ambiente de trabalho, que detém proteção constitucional, conforme dita o art. $7^{\circ}$ da Constituição Federal de 1988.

\title{
3.5 Da terceirização ilícita
}

O dano moral coletivo pode ainda se configurar nas relações de trabalho quando há presença da terceirização ilícita, isto é, a terceirização; conforme dita a súmula 331 do TST, é um instituto que per si é defeso; são nos casos de serviços de conservação e limpeza, serviços de vigilância e os serviços ligados à atividade meio do tomador de serviços. É a partir daí que se entende que será terceirização ilícita toda aquela atividade que estiver ligada à atividade fim do empregador. Nesse caso, os tribunais trabalhistas pátrios têm entendido que há o dano moral coletivo, como na ocasião do julgamento do Recurso Ordinário nº 01123-2007-118-15-00-7 originário do Tribunal Regional do Trabalho da $15^{\text {a }}$ Região.

No caso, observou-se que a empresa rural teria contratado serviços de duas empresas que forneceram 235 funcionários para trabalhar na lavoura, isto é, trabalho diretamente ligado à atividade fim da empresa, em uma completa afronta ao entendimento pacificado pelo TST, através da súmula 331, razão pela qual o acórdão restou ementado da seguinte maneira:

\begin{abstract}
DANO MORAL COLETIVO. TERCEIRIZAÇÃO ILÍCITA. TRATAMENTO DESUMANO. AFRONTAAOS ARTIGOS $5^{\circ}$ E $7^{\circ}$ DA CONSTITUIÇÃO DA REPÚBLICA. INDENIZAÇÃO DEVIDA. Optou a empresa, ao invés de admitir e assalariar seus próprios empregados, por contratar empresas terceirizadas para o fornecimento de mão de obra para a realização de tarefas inerentes à sua atividade empresarial, em afronta ao entendimento constante da Súmula $\mathrm{n}^{\circ} 331$ do C. TST. [...]. (BRASIL, 2010, on-line)
\end{abstract}

Nessa senda, é importante frisar que constitui grave ofensa à terceirização ilícita, uma vez que há uma precarização das relações de trabalho, sendo tal prática uma tentativa do empresariado de surrupiar os direitos garantidos aos trabalhadores, ferindo diretamente o valor social do trabalho previsto na Constituição, assim como a dignidade da pessoa humana; portanto, tal conduta é ensejadora do dano moral coletivo. Dessa forma, decidiu o TST no Recurso de Revista $\mathrm{n}^{\mathrm{o}}$ 12220011.2006.5.13.0002. Veja-se um excerto da ementa:

AGRAVO DE INSTRUMENTO do MINISTÉRIO PÚBLICO. DANO MORAL COLETIVO. TERCEIRIZAÇÃO ILÍCITA. ATIVIDADE FIM. Demonstrada violação do artigo $1^{\circ}$, IV, da Lei 7.347/85. Agravo de instrumento provido. RECURSO DE REVISTA DO MINISTÉRIO PÚBLICO. DANO MORAL COLETIVO. TERCEIRIZAÇÃO ILÍCITA. ATIVIDADE FIM. In casu, a reclamada incorreu na prática de ato ilícito ao contratar trabalhadores terceirizados para atuar em sua atividade fim, precarizando as relações de trabalho e desvirtuando a finalidade social do trabalho, restando configurado o dano moral coletivo [destacou-se]. Também assim o é porquanto verificado que houve violação de preceitos constitucionais, bem assim de disposições encartadas na legislação trabalhista consolidada, em razão da atitude ilícita praticada pela ré de não cumprir as normas nacionais relacionadas à proteção do emprego e dos trabalhadores, tendo-se, por consequência, a violação dos princípios constitucionais da dignidade da pessoa humana e do valor social do trabalho. Recurso de revista conhecido e provido [...]. (BRASIL, 2014, on-line)

Destaque-se, nesse ponto, que a Administração Pública também poderá ser responsável pela reparação de danos morais coletivos quando há terceirização de seus serviços, no momento em que determinados indivíduos são contratados diretamente, em desobediência ao provimento 
dos cargos efetivos por concurso público, conforme art. 37, inc. II, da Constituição. Foi dessa forma que julgou o Tribunal Regional do Trabalho da $4^{\mathrm{a}}$ Região, na ocasião do julgamento do Recurso Ordinário $\mathrm{n}^{\circ}$ 0175600-63.2009.5.04.0202, do qual se extrai a seguinte ementa:

\begin{abstract}
AÇÃO CIVIL PÚBLICA. TERCEIRIZAÇÃO ILÍCITA. INDENIZAÇÃO POR DANO MORAL COLETIVO. É ilícita a terceirização de atividades previstas em plano de cargos e salários da empresa, em detrimento de candidatos aprovados em concurso público. Violação à norma constitucional que exige a contratação de pessoal por intermédio de processo seletivo. Afronta aos princípios da impessoalidade e moralidade administrativas. Dano moral coletivo configurado. (BRASIL, 2012, on-line)
\end{abstract}

Nesse diapasão, é imperioso ressaltar a ofensa que se gera aos interesses difusos. No caso em espeque, a não contratação pela Administração Pública através de concurso público acarreta grave ofensa àqueles possíveis candidatos ao concurso público, sendo estes indivíduos indetermináveis e o objeto indivisível, de modo que se caracteriza o dano moral coletivo por ofensa aos interesses difusos. Dessa forma, julgou o Tribunal Superior do Trabalho o Recurso de Revista $n^{\circ}$ 43400-71.2008.5.14.0001, quando enfrentou a questão aqui levantada. Observe-se a ementa:

\begin{abstract}
RECURSO DE REVISTA - MINISTÉRIO PÚBLICO DO TRABALHO - INDENIZAÇÃO - DANO MORAL COLETIVO - TERCEIRIZAÇÃO ILÍCITA. A circunstância de a reclamada contratar mão de obra terceirizada para suprir necessidade de pessoal no exercício de atividade fim da empresa consiste em lesão que transcende o interesse individual de cada trabalhador de per si e alcança todos os possíveis candidatos que, submetidos a concurso público, concorreriam, nas mesmas condições, ao emprego no segmento econômico [destacou-se]. Recurso de revista conhecido e provido. (BRASIL, 2012, on-line)
\end{abstract}

Portanto, a terceirização ilícita, seja ela no âmbito privado ou público, poderá ensejar o dano moral coletivo por atingir interesses que transcendem a esfera individual.

\title{
Considerações Finais
}

O dano moral coletivo constitui uma ofensa principalmente à dignidade humana que transcende a individualidade, acarretando uma lesão aos interesses de uma coletividade. Contudo, essa percepção do dano moral coletivo decorre principalmente da ampliação ou da dimensão coletiva que ganhou o princípio da dignidade da pessoa humana.

Assim, o dano moral (extrapatrimonial) coletivo pode ser caracterizado como uma injusta lesão que fere diretamente os interesses e valores de certa coletividade, seja ela determinável ou não, ferindo principalmente a dignidade da pessoa humana. Assim, é uma verdadeira ofensa aos interesses metaindividuais.

Ressalte-se também que o dano moral coletivo não envolve necessariamente a ideia de dor ou abalo psíquico, mesmo porque na maioria das vezes a lesão se dirige a um grupo indeterminado de pessoas, sendo impossível a aferição da dor sofrida pelos indivíduos, razão pela qual esse liame psicológico se caracteriza apenas como consequência da lesão perpetrada. Nesta seara, imperioso dizer que, como o dano moral sempre esteve ligado àqueles aspectos psicológicos, para o dano moral coletivo, melhor seria utilizar a expressão dano extrapatrimonial coletivo, uma vez que esta está completamente desvinculada da ideia de dor, vexame, ligando-se exclusivamente ao abalo na esfera extrapatrimonial. 
$\mathrm{Na}$ esfera trabalhista, a figura do dano moral coletivo resta plenamente aceita pelos tribunais, caracterizando-se principalmente nas ocasiões em que há redução à condição análoga a de escravo, nas revistas íntimas, no descumprimento das leis trabalhistas, descumprimento das normas de medicina e segurança do trabalho, terceirizações ilícitas; todas estas situações são claramente atentatórias à dignidade da pessoa humana e, além disso, em todas essas ocasiões, existem valores protegidos de forma expressa na Constituição Federal de 1988, sendo, portanto, a condenação por danos morais coletivos importante instrumento para que a sociedade se posicione de forma enérgica quando há lesões desse viés.

\section{REFERÊNCIAS}

BITTAR FILHO, Carlos Alberto. Dano moral coletivo no atual contexto jurídico brasileiro. Revista de direito do consumidor. São Paulo, n. 12, p. 44-61, out./dez. 1994. Disponível em: $<$ http://egov.ufsc.br/portal/sites/default/files/anexos/30881-33349-1-pb.pdf > . Acesso em: 16 ago. 2014.

BRASIL. Consolidação das Leis do Trabalho. Decreto-lei n ${ }^{\circ} 5.452$ de $1^{\circ}$ de maio de 1943. Aprova a Consolidação das Leis do Trabalho. Disponível em: < http://www.planalto.gov.br/ccivil_03/decreto-lei/del5452.htm>. Acesso em: 9 ago. 2014.

. Tribunal Regional do Trabalho da $1^{\mathrm{a}}$ Região. Recurso Ordinário $\mathrm{n}^{\circ}$ 6853520115010077, 10 a turma, Rio de Janeiro, RJ, 25 jun. 2012. Disponível em: $<$ http://trt-1. jusbrasil.com.br/jurisprudencia/24642029/recurso-ordinario-ro-6853520115010077-rj-trt-1>. Acesso em: 11 set. 2014.

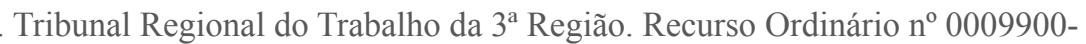
65.2008.5.03.0083, $7^{\mathrm{a}}$ Turma, Belo Horizonte, MG, 10 out. 2013. Disponível em: $<$ http://rt-3.jusbrasil.com.br/jurisprudencia/124083206/recurso-ordinario-trabalhista-ro-99200808303006-0009900-6520085030083 >. Acesso em: 16 ago. 2014.

. Tribunal Regional do Trabalho da $3^{\mathrm{a}}$ Região. Recurso Ordinário ${ }^{\circ} 0000742-$ 41.2012.5.03.0084, 6 $6^{\text {T }}$ Turma, Belo Horizonte, MG, 26 nov. 2013. Disponível em: $<$ http://trt-3.jusbrasil.com.br/jurisprudencia/124288527/recurso-ordinario-trabalhista-ro-742201208403004-0000742-4120125030084>. Acesso em: 05 set. 2014.

. Tribunal Regional do Trabalho da $3^{\mathrm{a}}$ Região. Recurso Ordinário $\mathrm{n}^{\circ} 0000556-$ 45.2013.5.03.0096, $5^{\text {a }}$ Turma, Belo Horizonte, MG, 25 abr. 2014. Disponível em: $<$ http://trt-3.jusbrasil.com.br/jurisprudencia/122830477/recurso-ordinario-trabalhista-ro-556201309603006-0000556-4520135030096>. Acesso em: 9 set. 2014.

. Tribunal Regional do Trabalho da $4^{\mathrm{a}}$ Região. Recurso Ordinário n ${ }^{\circ} 0175600$ 63.2009.5.04.0202, da 2 ${ }^{\text {a }}$ Vara do Trabalho de Canoas, Porto Alegre, RS, 11 jul. 2012. Disponível em: <http://trt-4.jusbrasil.com.br/jurisprudencia/128614984/recurso-ordinario-ro-1756006320095040202-rs-0175600-6320095040202>. Acesso em: 13 ago. 2014.

. Tribunal Regional do Trabalho da $6^{\mathrm{a}}$ Região. Recurso Ordinário n ${ }^{\circ} 0000028$ 82.2010.5.06.0144, $1^{\text {a }}$ Turma, Recife, PE, 6 jun. 2011. Disponível em: $<$ http://trt-6.jusbrasil.com.br/jurisprudencia/20001581/recurso-ordinario-trabalhista-ro-28822010506-pe-0000028-8220105060144>. Acesso em: 11 set. 2014. 
. Tribunal Regional do Trabalho da $10^{\mathrm{a}}$ Região. Recurso Ordinário $\mathrm{n}^{\mathrm{o}}$ 00245-2004-81110-00-3, 2 2 turma, Brasília, DF. 18 mar. 2005. Disponível em: <http://trt-10.jusbrasil.com.br/ jurisprudencia/8733383/recurso-ordinario-ro-245200481110003-to-00245-2004-811-10-00-3>. Acesso em: 05 set. 2014.

. Tribunal Regional do Trabalho da $10^{a}$ Região. Recurso Ordinário no 01606-2011-00810-00-0, 2a Turma, Brasília, DF, 29 maio. 2013. Disponível em: <http://trt-10.jusbrasil.com.br/ jurisprudencia/24519055/recurso-ordinario-ro-1606201100810000-df-01606-2011-008-10-00-0ro-trt-10>. Acesso em: 09 set. 2014.

Tribunal Regional do Trabalho da $15^{\mathrm{a}}$ Região. Recurso Ordinário nº 01123-2007-118$\overline{15-00-7}$, da vara do trabalho de Itapira, Campinas, SP, 19 mar. 2010. Disponível em: $<$ http:// trt-15.jusbrasil.com.br/jurisprudencia/18945897/recurso-ordinario-ro-13674-sp-013674-2010>. Acesso em: 12 set. 2014.

. Tribunal Regional do Trabalho da 20a Região. Recurso Ordinário no 00202-2003-00320-85-5, Aracajú, SE. 25 out. 2004. Disponível em: <http://trt-20.jusbrasil.com.br/jurisprudencia/4766587/202200300320855>. Acesso em: 08 set. 2014.

. Tribunal Superior do Trabalho. Embargos de declaração no 178000-13.2003.5.08.0117. Órgão Especial, Brasília, DF, 3 ago. 2012. Disponível em: <http://aplicacao5.tst.jus.br/consultaunificada2/inteiroTeor.do?action=printInteiroTeor\&highlight=true\&numeroFormatado= RR\%20-\%20178000-13.2003.5.08.0117\& base=acordao\&numProcInt=225646\&anoProcInt=2 006\&dataPublicacao $=03 / 08 / 2012 \% 2007: 00: 00 \& q u e r y=>$. Acesso em: 06 set. 2014.

. Tribunal Superior do Trabalho. Recurso de revista $n^{\circ} 15500-56.2010 .5 .17 .0132 .8^{a}$ Turma, Brasília, DF, 12 jun. 2013. Disponível em: $<$ http://tst.jusbrasil.com.br/jurisprudencia/23384016/recurso-de-revista-rr-155005620105170132-15500-5620105170132-tst $>$. Acesso em: 11 set. 2014.

. Tribunal Superior do Trabalho. Recurso de Revista $n^{\circ} 12220011.2006 .5 .13 .0002,6^{a}$ Turma, Brasília, DF, 19 mar. 2014. Disponível em: <http://tst.jusbrasil.com.br/jurisprudencia/121828205/recurso-de-revista-rr-1222001120065130002>. Acesso em: 13 set. 2014.

. Tribunal Superior do Trabalho. Recurso de Revista $n^{\circ} 43400-71.2008 .5 .14 .0001,4^{\mathrm{a}}$ Turma, Brasília, DF, 28 ago. 2012. Disponível em: < http://tst.jusbrasil.com.br/jurisprudencia/22269354/recurso-de-revista-rr-434007120085140001-43400-7120085140001-tst>. Acesso em: 13 set. 2014.

. Tribunal Superior do Trabalho. Súmula 331. Contrato de Prestação de Serviços Legalidade: I - A contratação de trabalhadores por empresa interposta é ilegal, formando-se o vínculo diretamente com o tomador dos serviços, salvo no caso de trabalho temporário (Lei $\mathrm{n}^{\circ}$ 6.019, de 03.01.1974). II - A contratação irregular de trabalhador, mediante empresa interposta, não gera vínculo de emprego com os órgãos da Administração Pública direta, indireta ou fundacional (art. 37, II, da CF/1988). (Revisão do Enunciado nº 256 - TST) III - Não forma vínculo de emprego com o tomador a contratação de serviços de vigilância (Lei n ${ }^{\circ} 7.102$, de 20.06.1983) e de conservação e limpeza, bem como a de serviços especializados ligados à atividade-meio do tomador, desde que inexistente a pessoalidade e a subordinação direta. IV - O inadimplemento das obrigações trabalhistas, por parte do empregador, implica a responsabilidade subsidiária do tomador dos serviços quanto àquelas obrigações, desde que haja 
participado da relação processual e conste também do título executivo judicial. (Alterado pela Res. 96/2000, DJ 18.09.2000) V - Os entes integrantes da Administração Pública direta e indireta respondem subsidiariamente, nas mesmas condições do item IV, caso evidenciada a sua conduta culposa no cumprimento das obrigações da Lei $n^{\circ}$ 8.666, de 21.06.1993, especialmente na fiscalização do cumprimento das obrigações contratuais e legais da prestadora de serviço como empregadora. A aludida responsabilidade não decorre de mero inadimplemento das obrigações trabalhistas assumidas pela empresa regularmente contratada. VI - A responsabilidade subsidiária do tomador de serviços abrange todas as verbas decorrentes da condenação referentes ao período da prestação laboral. Disponível em: <http://www.dji.com.br/normas_inferiores/enunciado_tst/tst_0331a0360.htm>. Acesso em: 12 set. 2014.

COSTA, Marcelo Freire Sampaio. Dano moral (extrapatrimonial) coletivo: leitura constitucional, civil e trabalhista. São Paulo: LTr, 2009.

MEDEIROS NETO, Xisto Tiago de. Dano moral coletivo. 2. ed. São Paulo: LTr, 2007.

MELO, Nehemias Domingos de. Dano moral trabalhista. São Paulo: Atlas, 2007.

SOUTO MAIOR, Jorge Luiz. O dano social e sua reparação. Revista LTr: Revista Legislação do Trabalho. São Paulo, v. 71, n. 11, p. 1317-1323, 2011.

\title{
COLLECTIVE MORAL DAMAGE IN LABOR LAW
}

\begin{abstract}
This work makes a critical analysis of the collective moral damage and its incidence in the Labor law field, through cases judged by Labor courts in Brazil. In Labor law, the collective moral damage has been very frequent, especially in cases of reduction of conditions analogous to slavery, body searches, noncompliance with Labor laws, and noncompliance with Safety and Occupational Health law.
\end{abstract}

Keywords: Labor Law. Collective Moral Damage. Non-Pecuniary Collective Damage. Trans-Individual Rights.

Data de recebimento: out/2014 - Data de aprovação: dez/2014 